\title{
Research on Technology Spillover's Bridge Effect between Bidirectional FDI and GVC Position-A Case of Chinese Manufacturing Industry
}

\author{
Pei Yu, Ge Peng \\ School of Economics, Wuhan University of Technology, Wuhan, China \\ Email: peguyvincent@hotmail.com, 18639405623@163.com
}

How to cite this paper: $\mathrm{Yu}, \mathrm{P}$. and Peng, G. (2019) Research on Technology Spillover's Bridge Effect between Bidirectional FDI and GVC Position-A Case of Chinese Manufacturing Industry. American Journal of Industrial and Business Management, 9, 845-853.

https://doi.org/10.4236/ajibm.2019.94057

Received: March 11, 2019

Accepted: April 9, 2019

Published: April 12, 2019

Copyright (c) 2019 by author(s) and Scientific Research Publishing Inc. This work is licensed under the Creative Commons Attribution-NonCommercial International License (CC BY-NC 4.0). http://creativecommons.org/licenses/by-nc/4.0/

\begin{abstract}
Focusing on technology spillover's bridge effect between bidirectional Foreign Direct Investment (FDI) and Global Value Chain (GVC) position of manufacturing industry, this paper first analyzes theoretical mechanism of bidirectional FDI's influence on GVC position, by taking into account technology spillover perspective, and then it verifies the theoretical framework by using 15 Chinese manufacturing sub-industries data in the latest ten years. The Generalized Least Squares regression results prove that technology spillover plays as a core channel of both Inward FDI's and Outward FDI's GVC position promotion effect, and the interactive development of bidirectional FDI can further significantly enhance this bridge effect.
\end{abstract}

\section{Keywords}

Bidirectional FDI in China, Technology Spillover Effect, GVC Position

\section{Introduction}

Since reform and opening up, China has assumed the dual status as both the world's second largest host country and outward foreign home country of Foreign Direct Investment (FDI). In the background of fully open economy, utilizing inward FDI (IFDI) and conducting outward FDI (OFDI) have become the important way for "Made in China" to participate in the division of Global Value Chain (GVC) led by multinational corporations (MNCs). The traditional Made in China has been passively embedded in the GVC division system with low-cost advantages such as cheap labor and resources, and has created a num- 
ber of Chinese miracles.

However, when the fourth industrial revolution marked by Industry 4.0 begins, Made in China faces the risky situation of being locked in low end of GVC and crowd-out effect, due to the high external dependence on core technology and the rising cost of traditional factor endowments. Meanwhile, high-end manufacturing backflow to Europe and the US caused by re-industrialization strategy, as well as developed countries' restrictions on China's investment in high-tech industries and the spread of de-globalization, have made unprecedented obstacle in the internationalization of Made in China. Therefore, how to use the bidirectional FDI effectively, and how to promote GVC position by technology spillover of IFDI and OFDPs harmonious development, will directly affect the realization of the sustainable development goal of Made in China, from big to strong and from full range to optimization.

The previous relevant studies mainly explore separately the impact of IFDI on host country's GVC position or OFDPs influence on GVC position of home country [1] [2] [3] [4], and there are few studies that incorporate IFDI and $O F D I$ into one framework and discuss their interaction. Therefore, based on the perspective of technology spillover's bridge effect, this paper innovatively integrates the harmonious development of bidirectional FDI and GVC position in the same theoretical framework, and analyzes the influences on GVC position of Chinese manufacturing industry, brought about by IFDI and OFDI. In general, it provides a new angle to in-depth understand China's fully open economy's effects on its GVC position.

\section{Theoretical Framework and Hypotheses}

Each link of GVC corresponds to a level of technology. Thus, the improvement of technical competence embodies the upgrading of GVC position [5]. Based on this perspective, technology spillover of bidirectional FDI would affect a country's GVC position. By combing the inner relationship between IFDI and $O F D I$ [6] [7] and also their influences on GVC position separately [8] [9] [10] [11], this paper analyzes theoretical mechanism of technology spillover's bridge effect between bidirectional FDI and GVC position, by taking into account the channels such as demonstration imitation effect, human capital effect and linkage effect, etc.

\subsection{The Impacts of IFDI on GVC Position through Technology Spillover}

1) Demonstration imitation effect. With advanced production modes, management concepts and sales experience, foreign investors can carry out production activities by using cheap production factors in the host country and obtain lucrative profits. In this process, host companies utilize the demonstration effect brought about by foreign invested companies to learn and imitate advanced technology, management concept and operation mode, which make it possible to realize technological transformation and regeneration, improve productivity 
in whole industry, and finally promote quality and added value of products.

2) Human capital effect. In order to ensure the effective implementation of management and operation of standardized production, foreign investors usually pay attention to training local employees, aiming at meeting international qualification of human resources. Therefore, through formal and informal interpersonal interactions of training programs, the spread of invisible knowledge and technology can be accelerated among employees, and as a result, GVC position can be augmented in the host country.

3) Competition effect. Foreign investors can capture market share by their specific advantages such as high-quality product, high popularity brand, and advanced technology, which will bring competitive pressure to local firms in the host country. Therefore, these firms will be forced to carry out R\&D and innovation activities, in order to promote both product and function upgrading on the GVC.

4) Linkage effect. It refers to the technology spillover effects brought about by foreign investors on their upstream or downstream industries. In the context of economic globalization, market competition is characterized by the competition of the whole value chain linked by upstream and downstream industries. Therefore, foreign investors have the incentive to promote technological progress of their upstream and downstream partners [12].

Hypothesis 1: Technology spillover effect of IFDI promotes host country's GVC position.

\subsection{The Impacts of OFDI on GVC Position through Reverse Technology Spillover}

1) Demonstration imitation effect. $O F D I$ can help developing countries to embed into the high value-added position on GVC dominated by developed countries. Through OFDI, firms in developing countries would learn cut-edge technologies from their partners in developed countries and feedback these gains to home, and then improve home country's GVC position.

2) Human capital effect. Developing countries set up overseas R\&D centers through $O F D I$ in developed countries, which helps skilled technicians to absorb advanced knowledge and management experience by communicating and exchanging with R\&D personnel in host countries. As a result, new technology and advanced management skills would flow back to home countries, and help to upgrade GVC position.

3) Linkage effect. Companies investing in developed countries accumulate advanced technology and market information through learning and demonstration effects, which can provide technological guidance and share market trends information for the downstream industries of home country. Besides, the high standards for products and services in developed countries and fierce competition in international market would force developing countries to upgrade technology to meet high standards.

Hypothesis 2: Technology spillover effect of OFDI promotes home country's 
GVC position.

\subsection{The Impacts of Bidirectional FDI on GVC Position through Technology Spillover}

Based on theory of Investment Development Path (IDP), the harmonious development between IFDI and $O F D I$ can be firstly realized by technology spillover effect, and then promote GVC position.

Figure 1 shows the mechanism framework of the bidirectional FDI's impacts on GVC position. On the one hand, technology spillover produced by IFDI creates precondition of $O F D I$. For instance, through competition effect, IFDI can optimize resource allocation and relief resource shortages in host countries. Meanwhile, IFDI can also introduce foreign advanced production technologies, management concepts through human capital flow and imitation effect, which help to narrow the technological gap between host and home countries. As a result, host countries' international comparative advantages will be enhanced, thereby promoting the expansion of $O F D I$ scale and strengthening $O F D I$ s promotion effects on GVC position by reverse technology spillover.

On the other hand, OFDI optimizes quality of IFDI through reverse technology spillover effect. With the gradual expansion of $O F D I$, personnel flow and learning effects will bring the advanced technology from host country back to home country, which will help to overcome technological barriers and enhance home country's ability to utilize high quality foreign capital. As a result, IFDIs promotion effects on GVC position by technology spillover will be enhanced. In sum, technology spillover plays as bridge effect between harmonious development of bidirectional FDI and GVC position.

Hypothesis 3: Technology spillover effect of bidirectional FDI promotes GVC position.

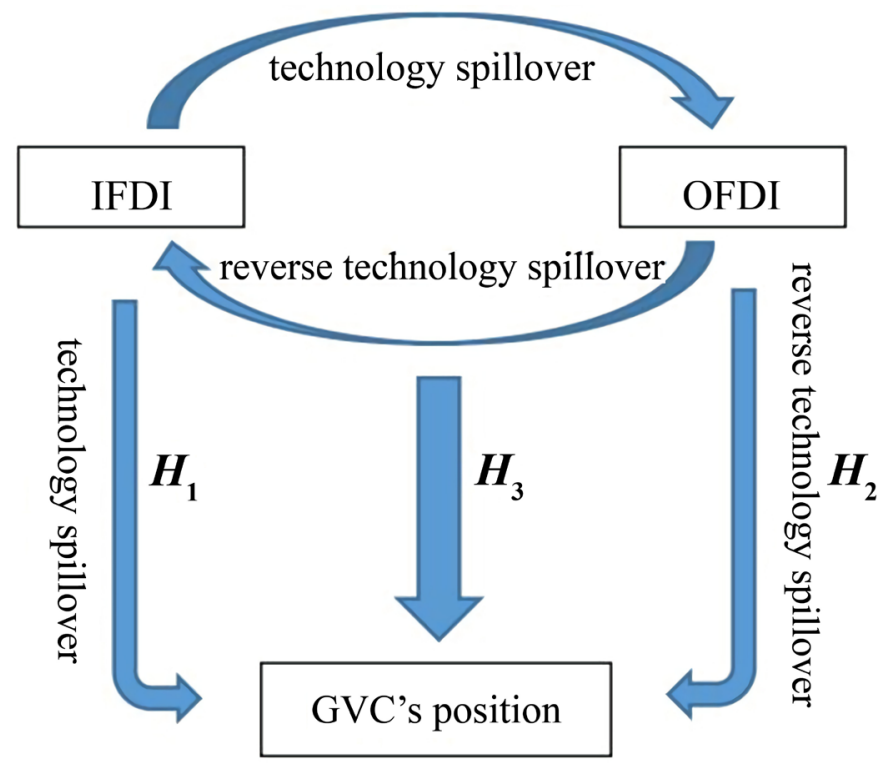

Figure 1. Framework of bidirectional FDI's impact on GVC position. 


\section{Empirical Test}

\subsection{Sample Selection}

According to the statistics of the Ministry of Commerce of the People's Republic of China, after official carrying out of Go Out strategy in 2000, China's OFDI has entered a stage of rapid development since 2003. Therefore, China's Foreign Direct Investment Statistics Bulletin has begun to count China's OFDI since 2003. In addition, when measuring GVC position of China's manufacturing sub-industries, this paper uses statistics from World Input and Output Database, in which the latest statistics are updated on the basis of situation in 2014. Therefore, the sample covers the period from 2003 to 2014. Furthermore, due to the differences of industrial classification between GBT and ISIC, this paper matches these two standards. As a result, 15 manufacturing sub-industries are filtered.

\subsection{Regression Model Specification}

Based on the theoretical framework, this paper sets following three models to verify the impacts of $I F D I, O F D I$ and bidirectional FDI on GVC position.

$$
\begin{gathered}
\ln G P O_{i t}=\alpha_{0}+\alpha_{1} \ln I F D I_{i t}+\alpha_{2} \ln I F D I_{i t} \times \ln T E C H_{i t}+\theta_{1} Z_{i t}+u_{i}+v_{t}+\varepsilon_{i t} \\
\ln G P O_{i t}=\beta_{0}+\beta_{1} \ln O F D I_{i t}+\beta_{2} \ln O F D I_{i t} \times \ln T E C H_{i t}+\theta_{2} Z_{i t}+u_{i}+v_{t}+\varepsilon_{i t} \\
\ln G P O_{i t}=\gamma_{0}+\gamma_{1} \ln I D L_{i t}+\gamma_{2} \ln I D L_{i t} \times \ln T E C H_{i t}+\theta_{3} Z_{i t}+u_{i}+v_{t}+\varepsilon_{i t}
\end{gathered}
$$

where $i$ and $t$ represent respectively the sub-industry and year. GPO represents GVC position. The three cross-variables describe the technological spillovers of IFDI, OFDI and bidirectional FDI. Control variables $Z$ include domestic supporting capacity $(D S C)$, industry export intensity $(E X S)$, capital input intensity $(K / L)$, and industry size $(S I Z E) . U, v$, and $e$ are respectively individual effect, time effect, random term. Each variable is logarithmically processed, in order to reduce the heteroscedasticity effects and time trend factors.

\subsection{Variables Specification}

This research focuses on the impact of bidirectional FDI interaction on GVC position in China's manufacturing industry. The specifications of main variables are as follow.

1) GPO. WWZ method is used to decompose total exports [13]. This method extends the value-added decomposition framework to the sector, bilateral, or bilateral sector level, and according to sources and final absorption of the export products' value added, the total gross exports are decomposed into sixteen various value-added and double counted components. It has greatly improved the accuracy of trade value added measurement. Based on this decomposition method, $G P O$ of sample industry $i$ is calculated as:

$$
\mathrm{GVC}_{-} \text {Position }_{i r}=\ln \left(1+\frac{\mathrm{DVA}_{\mathrm{INT} \_\mathrm{REX}} \mathrm{ir}_{i r}}{E_{i r}}\right)-\ln \left(1+\frac{\mathrm{FVA}_{i r}}{E_{i r}}\right) \text {. }
$$

where $i$ and $r$ represent the industry and country. GPO is replaced by 
GVC_Position + 1 if GVC_Position < 0 .

2) $I F D I$ and $O F D I$. Due to the limitation of statistics, this paper uses the proportion of each sub-industry's foreign capital in the whole manufacturing sector's foreign capital to multiply by whole manufacturing industries' actual usage of foreign capital to measure IFDI. And for measuring OFDI, it uses proportion of each sub-industry's export value in the whole manufacturing sector's export value to multiply by whole manufacturing industries' outward foreign direct investment value [14].

3) IDL. The formula of bidirectional FDI interaction index is

$$
D_{i t}(I O)=\left\{I F D I_{i t} \cdot O F D I_{i t} /\left[I F D I_{i t}+O F D I_{i t} / 2\right]\right\}^{1 / 2}[15] \text {, }
$$

which indicates the harmonious development level of bidirectional FDI.

4) TECH. This paper uses DEA-Malmquist productivity index model to measure Total Factor Productivity (TFP), which represents the effect of technology spillover. Specifically output value is measured by industry added value, labor input is measured by average industry employees, and capital input is measured by industry fixed assets. TFP is converted into a cumulative index.

In order to capture technology spillover's bridge effect between bidirectional FDI and GVC position, interactive terms of IFDI, OFDI and IDL with TFP are taken into account [16].

5) $D S C$. Domestic supporting capacity is measured by the proportion of domestic intermediates consumed by each sub-industry in total domestic intermediates consumed by the whole manufacturing industry [17].

6) EXS. Export intensity is measured by the proportion of China's each sub-industry's export value in the world export value in the same industry.

7) $K / L$. Capital input intensity is measured by the proportion of an industry's fixed assets in its employees.

8) $S I Z E$. Industry scale is measured by average industry employees.

Data of GPO, DSC and EXS are collected from WIOD. Data of other variables are from China Statistical Yearbook, China's Foreign Investment Statistics Bulletin, China Industrial Economics Statistical Yearbook, and National Bureau of Statistics of P. R. China.

\section{Empirical Results Analyzes}

In order to reduce the adverse effects caused by heteroscedasticity and autocorrelation, this paper uses Generalized Least Squares method to correct the above problems [18].

Model 1 to 3 in Table 1 respectively correspond to the influence of IFDI, $O F D I$ and bidirectional FDI interaction on GVC position of China's manufacturing industries.

Although IFDI generally does not promote GVC position of China's manufacturing industry, its interaction with technology spillover presents contrary results. Model 1 reveals that for every $10 \%$ increase of this interaction term, China's GVC position will be raised by $0.066 \%$. Therefore, technology spillover 
Table 1. Influence of bidirectional FDI on GVC position.

\begin{tabular}{|c|c|c|c|}
\hline Variables & Model 1 & Model 2 & Model 3 \\
\hline $\ln I F D I$ & $-0.0160^{\star * *}(-5.96)$ & & \\
\hline $\ln I F D I \times \ln T E C H$ & $0.0066^{* * \star}(11.48)$ & & \\
\hline $\ln O F D I$ & & $-0.0131^{\star \star \star}(-7.55)$ & \\
\hline $\ln O F D I \times \ln T E C H$ & & $0.0077^{\star * *}(12.89)$ & \\
\hline $\ln I D L$ & & & $-0.0280^{\star * \star}(-8.12)$ \\
\hline $\ln I D L \times \ln T E C H$ & & & $0.0145^{\star * \star}(12.99)$ \\
\hline $\ln D S C$ & $0.2344^{\star \star \star}(9.19)$ & $0.2373^{\star \star \star}(9.23)$ & $0.2366^{* * *}(9.38)$ \\
\hline $\ln E X S$ & $-0.0156^{\star * *}(-8.02)$ & $-0.0130^{* * *}(-4.35)$ & $-0.0128^{\star * *}(-4.25)$ \\
\hline $\ln K / L$ & $0.0109^{\star * \star}(4.01)$ & $0.0138^{\star * \star}(5.47)$ & $0.0138^{* * *}(5.56)$ \\
\hline $\ln S I Z E$ & $0.0020(0.89)$ & $0.0016(0.97)$ & $0.0022(1.42)$ \\
\hline _Cons & $0.0720^{\star \star}(2.50)$ & $0.0061(0.31)$ & $0.0190(0.91)$ \\
\hline Industry fixed effect & YES & YES & YES \\
\hline Time fixed effect & YES & YES & YES \\
\hline Hausman Test & Prob $>$ chi $2=0.0057$ & Prob $>$ chi $2=0.0002$ & Prob $>$ chi $2=0.0001$ \\
\hline Wald Test & Prob $>$ chi $2=0.0000$ & Prob $>$ chi $2=0.0000$ & Prob $>$ chi $2=0.0000$ \\
\hline Wooldridge Test & Prob $>F=0.0043$ & Prob $>F=0.0040$ & Prob $>F=0.0039$ \\
\hline FE or RE & $\mathrm{FE}$ & $\mathrm{FE}$ & $\mathrm{FE}$ \\
\hline
\end{tabular}

Note: 1) $\left.{ }^{*} \mathrm{p}, 0.10,{ }^{* *} \mathrm{p}, 0.05,{ }^{* * *} \mathrm{p}, 0.01 .2\right)$ Wald Test for heteroscedasticity test, Wooldridge Test for autocorrelation test. 3) $\mathrm{Z}$ value in parentheses.

is an important channel for IFDI promoting GVC position. Hypothesis 1 is approved. In reality, after financial crisis, China's government has actively encouraged foreign invested firms to establish overseas R\&D centers in China, extend product technology chain, and offer more employee training opportunities, in order to improve technology spillover effect and then to promote China's GVC position. From $O F D I$ perspective, Model 2 shows that $O F D I$ as well has negative influence on GVC position, but its interaction with technology spillover can significantly enhance China's GVC position. Hypothesis 2 is verified. This finding indicates that China's OFDI firms have effectively absorbed advanced technology from host countries, supplemented the shortage in China's manufacturing industry, and as a result, contributed to upgrading of GVC position. Regression results of bidirectional FDI in Model 3 uncover technology spillover's important bridge effect between bidirectional FDI and GVC position of China's manufacturing industries. Hypothesis 3 is affirmed. Moreover, the magnitude of the coefficient for interactive term in Model 3 is larger than that for one-way FDI. The harmonious development of bidirectional FDI can amplify technology spillover effects and then promote GVC position. From the perspective of control variables, $D S C$ and $K / L$ significantly promote GVC position. However, EXS s negative influence proves again China's low-end locked-in status on GVC. In 
addition, the coefficient of $S I Z E$ is not statistically significant. It seems that the efficiency of transforming cost advantage by economies of scale to productivity is still limited in China's manufacturing industry.

\section{Conclusions and Implications}

Based on technology spillover's bridge effect, this paper innovatively integrates $I F D I$ and $O F D I$ into one framework to explore the impacts of bidirectional FDI on GVC position. The empirical results on the basis of China's practice prove that, although transnational flow of capital does not promote GVC position, this effect can be reversed when technology spillover is taken into account. Moreover, the bridge effect of technology between the harmonious development of bidirectional FDI and promotion of GVC position is much more obvious. These empirical findings can offer some inspirations for industry development in China. First, in the context of fully open economy, the efficient combination of high-quality IFDI and stable $O F D I$ is important for China's manufacturing industry. China's government should change from passively absorbing IFDI to actively selecting $I F D I$ in order to promote the quality of IFDI. Meanwhile, OFDI should be continuously conducted for optimizing domestic resources allocation, promoting China's technology standards, and cultivating the international competitive advantages in China's manufacturing industry. Secondly, China's government needs to further amplify technology spillover effect, which is an important channel for realizing bidirectional FDI's promotion effects on GVC position. For instance, China's government should raise the threshold of IFDI in China's manufacturing industry, in order to upgrade the production process. In addition, $O F D I$ in manufacturing industry should be guided to the high-end fields for stronger reverse technology spillover effects and external interests, which can help China to transform from passively integrating into GVC to actively constructing it. Last but not least, Chinese firms should strengthen independent innovation competence and optimize input-output relation of R\&D activities, through linkage-learning-leverage path of OFDI.

\section{Conflicts of Interest}

The authors declare no conflicts of interest regarding the publication of this paper.

\section{References}

[1] Blomström, M. and Kokko, A. (1998) Multinational Corporations and Spillovers. Journal of Economic Surveys, 12, 247-277. https://doi.org/10.1111/1467-6419.00056

[2] Ge, S.Q. and Luo, W. (2015) Multinational Enterprises Entry and Industrial Structural of Manufacturing Sector in China: Based on Global Value Chain Perspective. Economic Research Journal, 11, 34-48.

[3] Brach, J. and Kappel, R. (2009) Global Value Chains, Technology Transfer and Local Firm Upgrading in non-OECD Countries. GIGA Working Papers.

[4] Yang, L.X. and Luo, Y.H. (2017) Outward Foreign Direct Investment and Global 
Value Chain Upgrading Effect. The Journal of Quantitative \& Technical Economics, 34, 54-70.

[5] Humphrey, J. (2004) Upgrading in Global Value Chains. Social Science Electronic Publishing.

[6] Yao, S.J., Wang, P., Zhang, J. and Ou, J.H. (2016) Dynamic Relationship between China's Inward and Outward Foreign Direct Investments. China Economic Review, 40, 54-70. https://doi.org/10.1016/j.chieco.2016.05.005

[7] Wang, S.Q. and Wang, S.L. (2017) Productivity Effects of Bidirectional FDI in Manufacturing Industry: Industry Differences and Estimation of Human Capital Threshold. Economic Review, 2, 102-114.

[8] Li, L., Liu, B. and Wang, X.X. (2017) Spillover Effect of Foreign Investment and Global Value Chain Participation of China. World Economy Studies, 4, 43-58.

[9] Li, Y. and Li, P. (2018) A Study on Heterogeneity Impacts of FDI on China Industries' Value Chain Upgrading. World Economy Studies, 5, 37-50.

[10] Zhang, H. and Wang, J. (2013) China's Foreign Direct Investment and Global Value Chain Upgrade. China Renmin University Press, Beijing.

[11] Li, H.B. and Wen, L. (2016) Does Two-Way Investment in Service Industry Improve Chinese Enterprises' Innovation Competence? International Economics and Trade Research, 32, 18-33.

[12] Wang, J.Y. and Blomström, M. (1992) Foreign Investment and Technology Transfer: A Simple Model. European Economic Review, 36, 137-155. https://doi.org/10.1016/0014-2921(92)90021-N

[13] Koopman, R., Powers, W., Wang, Z. and Wei, S.J. (2010) Give Credit Where Credit Is Due: Tracing Value Added in Global Production Chains. National Bureau of Economic Research. https://doi.org/10.3386/w16426

[14] Liu, H.Y. and Nie, F. (2015) Study on the Manufacturing Industrial Hollowing-Out Effect of China's OFDI. China Industrial Economics, 4, 83-96.

[15] Huang, L.Y., Liu, D.D. and Xie, H.Q. (2018) Research on the Harmonious Development of Outward Foreign Direct Investment and Inward Foreign Direct Investment. China Industrial Economics, 3, 80-97.

[16] Li, P., Jiang, Q. and Lin, Y. (2018) FDI and "Trap of International Division of Labor"-Based on View of GVC Embeddedness in Developing Host Countries. Journal of International Trade, 6, 119-132.

[17] Li, F. (2015) The Status of International Division of Labor under Global Value Chain: An Analysis Based on Added Value. International Economics and Trade Research, 31, 31-42.

[18] Wang, Y.Y. and Lin, H.C. (2015) Effects of Global Value Chain Embeddedness on Industrial Transformation and Upgrading: An Empirical Study on China's Industrial Panel Data. Journal of International Trade, 11, 51-61. 